or avoid effiorescence are tedious and seldom observed in practice, no suggestions are forthcoming on how best to eradicate this trouble; superficially this may be done by various expedients, but the result is seldom permanent, if conditions inside the brickwork are unfavourable or if there is recurrent reaction between water and vulnerable constituents in the cement.

On the question of frost damage to bricks, this appears to be rare in normal external walls between damp-proof course and eaves, although not uncommon in parapets, free-standing walls, and retaining walls, especially where insufficient care has been exercised in selection of special quality bricks. Thermal, and particularly moisture, expansion of bricks are important factors; the former happens with all building materials, its effects are well known and usually allowed for at the design stage; the latter form of expansion is not so generally recognized, this property only receiving scientific attention in recent years. The practical implications of moisture expansion, as set forth in this publication, may be summarized thus: bricks should not be used straight from kiln, or on site unless stacked for at least one week; special attention must be paid to storage before use if bricks are to be laid in high-strength mortar, which will become rigid very quickly; short returns in brickwork, specially vulnerable to cracking by expansion, are to be avoided; in long walls, expansion joints should be provided capable of accommodating an expansion of $\frac{3}{8} \mathrm{in}$. in $40 \mathrm{ft}$. Quality control testing of bricks, envisaged in the new British Standard $3921: 1965$, is here strongly and rightly urged; acceptance of 20-year-old test reports, still occasionally proffered by manufacturers of bricks, should be refused.

\title{
MINERALS OF THE SEA
}

A SURVEY and understanding of the geology of the sea-floor, implying the four oceans and the shallower seas that feed them, equally a knowledge of the organic and inorganic constitution of sea-water itself, are not new concepts in the realms of exploration or exploitation of the resources of the Earth, but much more is to-day being heard and learnt of this fascinating subject because of the universally intensified research efforts being made in its contemporary study. From the original Challenger expedition to the present Mohole project, the story of the oceans and that greater part of the Earth's crust which they conceal, has been slowly but very surely growing. Scientific interest, in stature, far outweighs that of economic, commercial investigations into the problems of the oceans, but that state of things is probably destined to be upset, if not reversed, in the not-too-distant future. All over the world the energy, food and mineral resources of the oceans are being re-appraisod, explored and, where feasible, exploited in the interests of mankind. Britain is by no means behind in the quest, and this does not mean simply 'North Sea oil and gas prospects'.

In September 1965 there began a relatively little pub. licized investigation into the possibilities of long-term exploitation of the oceans and their resources, sponsored by the Commercial Oceanology Study Group, a consortium of six British companios: British Petroleum, Richard Costain, Hawker Siddeley Group, Imperial Chemical Industries, Rio-Tinto Zine Corporation, and Unilever. This joint project is expocted to last at least a year. According to an article entitled "Minerals of the Sea" (BP Magazine, No. 17; Autumn 1965. The British Petrole um Co., London), each company is alrcady working in different but related fields of oceanology; each will ultimately contribute its own particular knowledge and experience to the study. The article itself is an extract from the book, World Beneath the Oceans, by Dr. T. F. Gaskell (courtesy of Aldous Books, London, 1965); Dr. Gaskell, with Mr. D. C. Ion, both of British Petroleum, are members of this Study Group.

This particular article is devoted specifically to the minerals of the sea, the salts it carries and deposits, and the natural cycle of meteorological and geological events which, through millions of years of time, have given rise to them. Salinity measurements through the entire width and depth of the oceans have been going on during the past eighty years or so, and the chemical composition of sea-water is well established; the problem is, how are we going to extract or mine some of the more valuable products it contains on an economic scale? As Dr. Gaskell rightly points out, shortage of terrestrial freshwater, as world population increases, must inevitably be made good by water processed from the sea; in fact, water will become one of the most important products of the sea. Other examples are magnesium (there are 4 million tons of magnesium dissolved in every cubic mile of sea-water), for which the process is already perfected; bromine, for the photographic industry and for producing anti-knock compounds for petrol; gold, the pipe-dream of men for yoars past: ". . . there is more gold in the sea than there is in use now", but commercially this problem has not yet been solved. Iodine is obtained from plants and animals of the sea; lobsters collect cobalt; the oyster gathers stray atoms of copper; and so on. The origin of petroleum, actually still an unsolved mystery, is in modern theories intimately bound up with the sea; sooner or later this secret will be unfolded, perhaps when we know more about the ocean floor itself.

\section{THE MOLE: ITS ADAPTATION TO LIFE UNDERGROUND}

$\mathrm{T}$ HE increased economic importance of the mole (Talpa europaea) as a farm pest has engendered renewed research into its behaviour and structure. The Ciba Foundation guest meeting on "The Mole: its Adaptation to an Underground Environment", held on January 5 and 6 , was attended by approximately thirty persons and eleven papers wero contributed covering a wide variety of topies. There were also several films, tape recordings and demonstrations, providing a very varied programme.

The first day of the meeting was mainly concerned with behaviour. At the beginning of the symposium the mole was considered to be almost exclusively subterranean, continually burrowing in search of food. By the end of the meeting this picture had changed greatly. Dr. K.
Mellanby showed that different moles used established burrows over and over again. Natural flooding proved that they could migrate over considerable distances and return after flood waters had receded. Mr. A. T. B. Rudge had succeeded in developing a trap for catching live moles. $\mathrm{He}$ had constructed monitored artificial burrows of wire mesh and shown that moles had periods of activity lasting $2-3 \mathrm{~h}$, followed by rest periods of $3-4 \mathrm{~h}$. This rhythm continued day and night. These findings were confirmed in the field by tagging moles with radioactive silver or cobalt sources attached to their tails. In their active periods they were continually running along their burrows (maximum speed up to 2.5 m.p.h.), only stopping for food that had fallen by chance into their runs. Moles did not often tunnel except while making 
repairs. Mr. P. Morris showed, by investigating food taken by various animals (for example, species of owls), that moles must often come to the surface, probably mostly at night, to be caught by these predators. Other investigations in France under freak drought conditions gave supporting evidence, as many moles were caught in traps placed on the ground surface. Dr. F. Raw gave details of the food theoretically available to moles. Earthworms, wire-worms, molluses and insect larvae seemed to form the possible basic diet. Mr. D. W. Yalden finished the day's session by describing the skeletal adaptations to locomotion. The session on behaviour thus presented a very different view of the behaviour of the mole to that normally assumed. It habitually uses preformed tunnels, during its waking periods it is continually searching for food, which it finds by chance encounter as it moves through its tunnels, and it is occasionally a surface dweller, probably mainly at night.

The second session, on microscopy, began with an account of the mole's pituitary gland by Prof. R. L. Holmes, who showed that there were no basic differences from the pituitary gland of other animals. The senses of the mole were described by Dr. T. A. Quilliam. The eyes had a very small number of receptor elements and there was a cellular lens. The mole had a snout packed with Eimer's organs that probably served for tactile recoption. There were also innervated vibrissae around the snout and in the tail. The ear was little different to that in other animals, although there were less than two turns to the cochlea. The fine structure of the olfactory mucosa was considered by Dr. P. Graziadei. He showed that the olfactory mucosa was large in extent (as were the olfactory bulbs of the brain). The receptor cells were ciliated, although some of these cells bore only one cilium and were not so closely packed together as in other mammals. The mucosa contained more supporting cells. Drs. R. Lund and $J$. Lund considered the central visual pathways and showed that they were poorly developed although moles could be taught to discriminate between light and dark. Dr. B. H. Crawford outlined physical methods that wero available to investigators to allow recordings to be made in the mole's tunnel, of light, sound, vibrations, heat and some other modalities, to see what sensory clues of the surroundings were available. Dr. M. Lobban outlined her studies on Arctic coal-miners and explained how the circadian rhythms were affected by the unnatural conditions under which the men work, in some ways analogous to those experienced by the mole. She pointed out that moles would be very useful animals for investigation of circadian rhythms. It seemed from the papers in this section that the mole has eyes that have little discriminatory abilities, a very well-developed olfactory sense, an auditory sense and complex tactile receptors in the vibrissae and in Eimer's organs in the snout. Whether the latter organs could detect other environmental features was left uncertain.

The symposium is eventually to be published in full as a supplement to the Journal of Zoology, Proceedings of the Zoological Society of London.

\section{C. BARBER}

\title{
SCATTERING OF ELECTROMAGNETIC WAVES BY ELECTRO-ACOUSTIC PLASMA WAVES
}

\author{
By P. F. LITTLE and S. M. HAMBERGER \\ U.K. Atomic Energy Authority Research Group, Culham Laboratory, near Abingdon, Berkshire
}

T HIS article reports some preliminary measurements of the scattering of an incident beam of microwaves by self-excited plasma waves in a mercury are column; from these results we derive an experimental dispersion curve for the plasma waves which we compare with a dispersion curve measured directly with Langmuir probes in the column. In this manner we identify the waves responsible for the scattering as propagating electro-acoustic waves, which are known to be present in the positive column of low-density arcs. Both selfexcited and extcrnally excited waves of this type have been observed ${ }^{1,2}$. Their phase velocity is approximately $c_{s}=\left(K T_{e} / M\right)^{\frac{1}{3}}$, where $K T_{e}$ is the electron thermal energy and $M$ the ion mass: in our plasma $c_{s} \approx 10^{5}$ $\mathrm{cm} / \mathrm{sec}$.

Let us write for the incident electromagnetic wave the frequency and wave vector $\omega_{1}$ and $\mathbf{k}_{1}$; the fluctuations in plasma density may be represented by a spectrum of

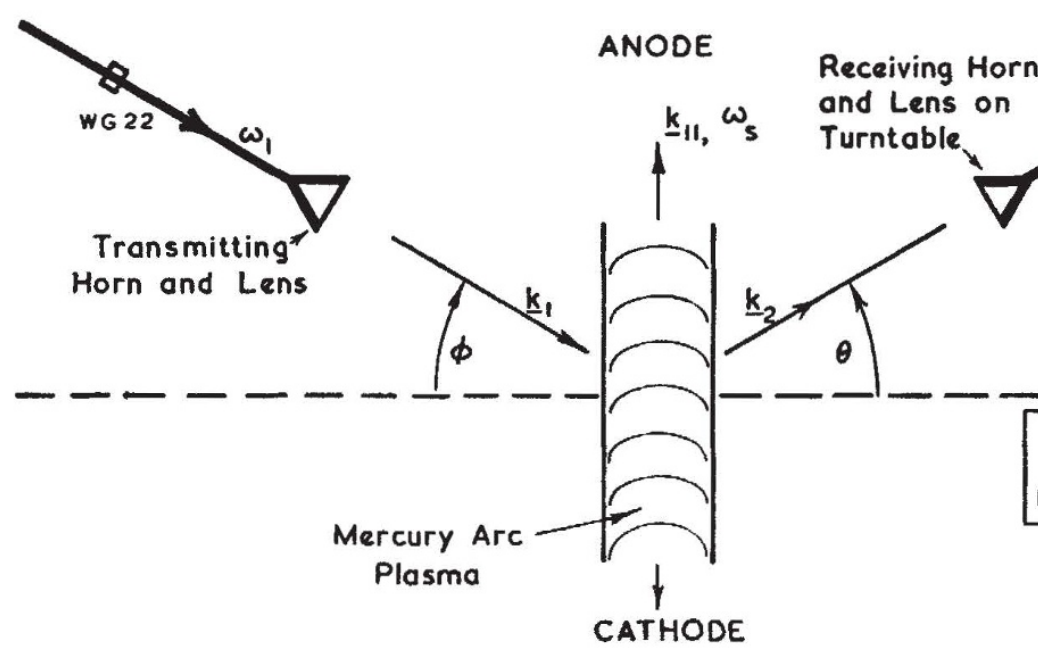

Fig. 1. Schematic arrangement of apparatus
WG 22
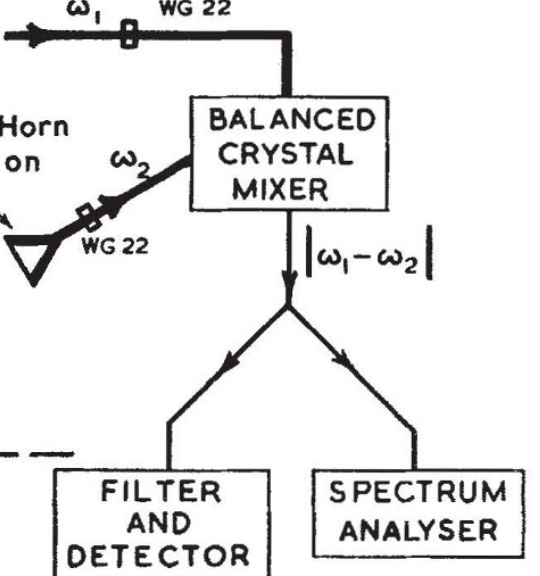

PEN RECORDER 